\title{
Cellular wall of Eucalyptus grandis under influence of growth regulators - chemical-anatomical aspects
}

\author{
Regina Pereira*, Maria Monteiro, Heber Abreu \\ From 5th Congress of the Brazilian Biotechnology Society (SBBIOTEC) \\ Florianópolis, Brazil. 10-14 November 2013
}

This research was caried out to understand the behavior of growth regulators (giberelic acid $\left(\mathrm{GA}_{3}\right)$ e 6-benzilaminopurin (BAP) on lignification system of Eucalyptus grandis (FORMER Hill Maiden). After $\mathrm{GA}_{3}$ (alone) and BAP (combined) applications, analyses were carried out. These regulators were applied by a atomization system at different concentrations levels. Anatomical analysis, including Mäule and Wiesner test as well as chemical analysis such as insoluble (Klason) and dioxane lignin were carried out as well. Infrared spectroscopy, methoxyl determination (Seizel Method) and total protein (Kjedahl Method) were performed. Synergism was suggested for $\mathrm{G}_{[1]} \mathrm{C}_{[1]}$ treatment, at following concentrations: $49,13 \mu \mathrm{M}$ and $111 \mu \mathrm{M}$. These treatments decreasing around $20 \%$ of lignin. In spite of infrared spectra that showed G/S composition, lignin GS, HG were confirmed by methoxyl content, suggesting regulators action on lignin biosynthesis and lignin structural modification. Positive Mäule and Wiesner test were observed, while protein did not modified significatively.

Submit your next manuscript to BioMed Central and take full advantage of:

- Convenient online submission

- Thorough peer review

- No space constraints or color figure charges

- Immediate publication on acceptance

- Inclusion in PubMed, CAS, Scopus and Google Scholar

- Research which is freely available for redistribution 